\title{
CORRIGENDUM
}

\section{Phosphorylation of MCT-1 by p44/42 MAPK is required for its stabilization in response to DNA damage}

S Nandi, LS Reinert, A Hachem, K Mazan-Mamczarz, HL Hsu, P Hagner, H He and RB Gartenhaus

Oncogene (2007) 26, 2674. doi:10.1038/sj.onc.1210447

\section{Correction to:}

Oncogene (2007) 26, 2283-2289. doi:10.1038/sj.onc.1210030; published online 2 October 2006

Since the publication of the above manuscript, the authors found that Dr HL Hsu had not been included in the list of authors. The correct list is given above.

Dr Hsu is affiliated with National Health Research Institutes, Zhunan Towan, Miaoli County, Taiwan, ROC. 